\title{
ANALISIS EFIKASI DIRI DAN HASIL BELAJAR BERBASIS E-LEARNING PADA MAHASISWA PROGRAM STUDI PENDIDIKAN MATEMATIKA
}

\author{
Stefania Baptis Seto $^{1^{*}}$, Lely Suryani ${ }^{2}$, Maria Goretty Diciloam Bantas ${ }^{3}$ \\ 1,2,3 Program Studi Pendidikan Matematika Universitas Flores \\ Jln. Sam Ratulangi, Kelurahan Paupire, Ende, NTT \\ ${ }^{*}$ Corresponding Author : stefaniseto@ gmail.com

\section{Info Artikel} \\ Sejarah Artikel: \\ Diterima: 01/07/2020 \\ Direvisi: 08/07/2020 \\ Disetujui: $17 / 09 / 2020$ \\ Keywords: Self- \\ efficacy, learning \\ outcomes, E-learning

\section{Abstract} \\ The purpose of this study is to see the relationship between self-efficacy and e-learning-based \\ learning results in students of semester 4 of Flores university mathematics education study \\ program. The research method used in this study is quantitative research, with linear \\ regression analysis using SPSS with a random sample of 40 fourth semester students. The \\ data analysis techniques used are the Prerequisite Test (Kolmogorov-Smirnov Normality \\ Test) and its research Hypothesis test using Pearson Bivariate correlation analysis with the \\ help of SPSS. The results of this study show self-efficacy $(X)$ has a positive influence on $e$ - \\ learning based Learning Results $(Y)$ known from the results of correlation analysis obtained \\ from the value of $R$ count to $X$ to $Y$ of 0.895 and the value of significance between $X$ to $Y$ \\ obtained two asterisks (**) so that there is a positive influence with a significance level of \\ $1 \%$. In other words, better or better self-efficacy will increase the learning outcomes of the \\ students themselves.
}

\begin{abstract}
Abstrak
Tujuan dari penelitian ini untuk melihat hubungan antara efikasi diri terhadap hasil belajar pembelajaran berbasis e-learning pada mahasiswa semester 4 program studi pendidikan matematika universitas Flores. Metode penelitian yang digunakan dalam penelitian ini adalah penelitian kuantitatif, dengan analisis regresi linear menggunakan SPSS dengan sampel di ambil secara random berjumlah 40 Mahasiswa semester IV. Teknik analisis data yang digunakan adalah Uji Prasyarat (Uji Normalitas Klomogorov-Smirnov) dan uji Hipotesis penelitiannya dengan menggunakan analisis korelasi Bivariate Pearson dengan bantuan SPSS. Hasil penelitian ini menunjukkan Efikasi Diri (X) mempunyai pengaruh yang positif terhadap Hasil Belajar berbasis e-learning (Y) diketahui dari hasil analisis korelasi diperoleh dari nilai $\mathrm{R}$ hitung untuk X terhadap $\mathrm{Y}$ sebesar 0.895 dan nilai signifikansi antara X terhadap $\mathrm{Y}$ diperoleh dua tanda bintang $(* *)$ sehingga ada pengaruh positif dengan taraf signifikansi 1 $\%$. Dengan kata lain semakin meningkatnya atau semakin baiknya Efikasi Diri maka akan meningkat pula hasil belajar dari mahasiswa itu sendiri.
\end{abstract}

\footnotetext{
"Alamat korespondensi:

Program Studi Pendidikan Matematika

Fakultas Keguruan dan Ilmu Pendidikan Universitas Flores,

(C) 2020 Program Studi PGSD Universitas Flores

Jln. Sam Ratulangi, Kelurahan Paupire, Ende, NTT

Email: primagistrauniflor@ gmail.com

E-mail: stefaniseto@gmail.com
} 


\section{PENDAHULUAN}

Pendidikan pada masa ini terbilang kurang efektif dikarenakan pandemic virus corona. Sebagian besar lembaga pendidikan mengambil tindakan untuk menggunakan pembelajaran jarak jauh atau pembelajaran dari jaringan. Pembelajaran jarak jauh yang sedang dilaksanakan pada saat ini sangat berpengaruh pada hasil belajar. Pembelajaran dari jaringan atau learning from home dengan menggunakan e-learning sudah digunakan oleh para para dosen atau pengajar sebelum adanya pandemic Covid-19 ini. Pembelajaran secara daring adalah satu alternatif untuk menekan penyebaran Covid-19 di lingkungan perguruan tinggi. Pandemic Covid-19 ini berdampak buruk bagi semua dunia dalam segala aspek, baik dari aspek ekonomi, social, pariwisata juga dalam aspek Pendidikan.

Dalam aspek Pendidikan, Menteri Pendidikan dan Kebudayaan Republlik Indonesia dalam Surat Edaran Nomor 4 Tahun 2020 tentang pelaksanaan kebijakan Pendidikan dalam masa darurat penyebaran covid tersebut, dijelaksan bahwa proses pembelajaran dilaksanakan di rumah melalui pembelajaran daring baik untuk para siswa siswi maupun bagi para mahasiswa. Agar proses belajar mengajar tetap berjalan dengan baik maka sekolah tetap melakukan pembelajaran jarak jauh, dengan cara memberikan tugas, atau mengunjungi tempat tinggal peserta didik.

Di Lembaga perguruan tinggi pun perkuliahan tetap dijalankan melalui system daring. Salah satunya yaitu menggunakan aplikasi E-Learning. sebagai mana yang diungkapkan oleh Nakayama bahwa dari semua literatur dalam e-learning mengindikasikan bahwa tidak semua peserta didik akan sukses dalam pembelajaran online. Ini dikarenakan faktor lingkungan belajar dan karakteristik peserta didik. (Nakayama M, Yamamoto $\mathrm{H}$, 2005).

Yazdi (2014) dalam penelitiannya mengemukakan bahwa e-learning adalah model pembelajaran yang ada dibuat dalam format digital melalui peralatan elektronik dengan tujuan memperluas akses terhadap pendidikan publik, sehingga belajar modul bisa diakses mudah tanpa ruang dan waktu dibatasi, interaktif dan efektif. Dalam penelitian ini peneliti dan penulis jurnal ini memiliki kesamaan yaitu mengukur hasil belajar peserta didik dari implementasi media online. Rahmawati(2016), mengemukakan bahwa pembelajaran SSCS berbantuan Schoology diharapkan menjadi solusi dari masalah. Tujuannya untuk mengetahui tingkat kesadaran metakognisi, kemampuan awal dan akhir berpikir kreatif matematik, menganalisis kemampuan berpikir kreatif matematik ditinjau dari kesadaran peningkatan kemampuan berpikir kreatif matematik peserta didik. Kesamaan dalam penelitian ini dengan Penelitian Tri Rahmawati dan Sugianto mengukur tingkat kesadaran metakognisi sedangkan peneliti mengukur hasil belajar peserta didik.

Setiap lembaga perguruan tinggi para dosen sudah menggunakan E-Learning dalam proses perkuliahan. Begitu juga pada Universitas Flores. Pembelajaran dengan ELearning merupakan suatu tuntutan yang harus dilakukan oleh para pengajar demi meningkatkan mutu dari pengajar itu sendiri. Di Uniflor, Khususnya pada program studi pendidikan matematika, sebagian besar para dosen sudah mulai menggunakan E-Learning. Sangat diharapkan dengan pembelajaran berbasis media online ini para mahasiswa dapat memahami materi ajar yang diberikan dosen, dan mampu menyesuaikan diri dengan pembelajaran daring ini. Perolehan hasil belajar yang memuaskan dalam pembelajaran daring dengan menggunakan E-Learning ini sangat terpegantung dari diri mahasiswa itu sendiri. Bagaimana ia mampu menyesuaikan dengan masa pembelajaran ini, dan bagaimana ia mampu mengatur dirinya untuk lebih bersikap aktif dan kreatif dalam pembelajaran daring ini.

Efikasi diri menurut (Alwisol, 2005) dapat diperoleh, diubah, ditingkatkan atau diturunkan, melalui salah satu atau kombinasi empat sumber, yakni pengalaman menguasai sesuatu prestasi (performance accomplishment), pengalaman vikarius (vicarious experiences), persuasi sosial (social 
persuation) dan pembangkitan emosi (emotional/ physiological states). Orang yang memiliki efikasi diri yang tinggi akan memiliki keyakinan mengenai kemampuannya dalam mengorganisasi dan menyelesaikan suatu tugas yang diperlukan untuk mencapai hasil tertentu dalam berbagai bentuk dan tingkat kesulitan. Hal ini berdampak self regulated learning juga akan tinggi. Ia akan mampu mengelola secara efektif pengalaman belajarnya sendiri di dalam berbagai cara sehingga mencapai hasil belajar yang optimal. Efikasi diri yang rendah akan sangat mempengaruhi seseorang dalam menyelesaikan tugasnya untuk mencapai hasil tertentu. Hal ini dapat dikaitkan dengan kurangnya informasi tentang kemampuan para siswa untuk yakin pada dirinya sendiri dalam mengerjakan tugas yang diberikan kepada mereka.

Bandura (dalam Suseno, 2012), bahwa perbedaan tingkat efikasi diri di pengaruhi oleh beberapa faktor, yaitu (1) Sifat tugas yang dihadapi, semakin kompleks dan sulit suatu tugas bagi seseorang maka semakin besar keraguan terhadap kemampuan nya begitu pula sebaliknya, (2) Satus seseorang dalam lingkungan. Seseorang yang memiliki status sosial lebih tinggi akan memiliki tingkat efikasi diri yang tinggi pula dibandingkan seseorang yang berstatus sosial lebih rendah, (3) Informasi tentang kemampuan diri. Efikasi diri akan meningkat jika seseorang mendapatkan informasi yang positif tentang dirinya, demikian sebaliknya efikasi diri akan menurun jika seseorang mendapatkan informasi negatif mengenai kemampuannya. Efikasi diri akademik dimaknai sebagai keyakinan yang dimiliki individu, bahwa dia mampu mencapai keberhasilan akademik (Christiana, 2018). Hal senada disampaikan oleh Murphy (dalam Johnson, 2017) yang menyatakan iklim akademik dan efikasi diri akademik berkorelasi positif dengan kinerja akademik mahasiswa, terbukti sejumlah 276 mahasiswa yang memiliki keyakinan dan berhasil menyelesaikan tugas akhir sebagai pra syarat melakukan ujian. Sehingga dapat disimpulkan bahwa efikasi diri akademik merupakan keyakinan individu mengenai kemampuannya dalam menyelesaikan atau menjalankan tugas akademik. Menurut Hamalik Oemar (2008), hasil belajar merupakan terjadinya perubahan tingkah laku pada diri seseorang yang dapat di amati dan di ukur bentuk pengetahuan, sikap dan keterampilan. Perubahan tersebut dapat diartikan sebagai terjadinya peningkatan dan pengembangan yang lebih baik sebelumnya yang tidak tahu menjadi tahu. Sedangkan Sudjana (2010) menyatakan bahwa hasil belajar ialah kemampuan-kemampuan yang dimiliki siswa setelah ia menerima pengalaman belajar. Berdasarkan pengertian diatas dapat disimpulkan bahwa hasil belajar merupakan perubahan tingkah laku pada diri seseorang dan dapat diukur dalam bentuk kemampuan pengetahuan, sikap dan keterampilan.

Dalam lingkungan perguruan tinggi hasil belajar mahasiswa dinyatakan dalam bentuk hasil studi. Hasil belajar yang memuaskan akan diperoleh mahasiswa jika mahasiswa tersebut menyadari bahwa posisi duduk juga berpengaruh dalam proses perkuliahan (Seto, Bantas: 2020). Oleh karena itu tujuan penelitian ini untuk menganalisis efikasi diri terhadap hasil belajar pembelelajaran berbasis e-learning pada mahasiswa semester 4 program studi pendidikan matematika universitas flores. Urgensi penelitian ini pula dilakukan adalah untuk tetap menjaga kualitas pendidikan serta daya juang yang tinggi seperti semangat hidup, rasa optimis yang besar terhadap kesuksesan sehingga diharapkan mahasiswa dapat sukses menjalani kehidupan di perguruan tinggi dan mempunyai prestasi yang optimal walaupun proses pembelajaran menggunakan e-learning.

\section{METODE PENELITIAN}

Penelitian yang digunakan adalah penelitian kuantitatif, dengan analisis regresi linear menggunakan SPSS, yng menjadi Populasi dalam penelitian ini adalah Mahasiswa Program Studi Pendidikan Matematika dengan sampel di ambil secara random berjumlah 40 Mahasiswa yang sedang duduk di semester IV. Instrumen yang 
diganakan untuk mengumpulkan data berupa angket dengan menggunakan skala Likert dan disebarkan kepada mahasiswa secara online dengan menggunakan Google Form. Instrument angket yang disebarkan kepada mahasiswa, telah divalidasi oleh Dosen Psikologi Catarina Novianti, Penelitian dilaksanakan pada bulan Februari sampai dengan bulan April 2020. Teknik analisis data yang digunakan adalah Uji Prasyarat (Uji Normalitas Klomogorov-Smirnov). Uji ini digunakan untuk mengetahui apakah data yang diperoleh berasal dari sampel dan populasi yang berdistribusi normal atau tidak, yang selanjutnya akan di uji Hipotesis penelitiannya dengan menggunakan analisis korelasi Bivariate Pearson dengan bantuan SPSS.

\section{HASIL DAN PEMBAHASAN}

\section{Uji Validitas dan Reliabilitas}

\section{a. Uji Validitas Angket Efikasi Diri}

Berdasarkan hasil analisis korelasi product moment dengan menggunakan bantuan SPSS versi 0.20 maka diketahui dari 45 butir soal instrument angket terdapat 5 butir soal yang tidak valid dilihat dari hasil korelasi yang kemudian dibandingkan dengan nilai $\mathrm{R}$ tabel. $\mathrm{R}$ tabel dicari pada signifiklan 5\% dengan uji 2 sisi dan $n=24$ (n)-1= 23, maka di dapat $r$ tabel sebesar 0.413 berdasarkan hasil analisis didapat nilai korelasi untuk butir soal nomor 1, 2, 10, 19, 33 kurang dari 0.413. maka dapat disimpulkan bahwa itemitem tersebut tidak berkorelasi signifikan dengan skor total (dinyatakan tidak valid) dan harus dikeluarkan.

\section{b. Uji Reliabilitas Angket Efikasi Diri}

Dari hasil analisis di dapat nilai Alpha sebesar 0.895 , sedangkan nilai $r$ kritis (uji 2 sisi) pada sgnifikansi 5\% dengan $n=40$, di dapat sebesar 0.312. maka dapat disimpulkan bahwa butir-butir instrument penelitian tersebut reliable.

\section{Uji Normalitas}

Berdasarkan tabel output SPSS pada Tabel 1, diketahui bahwa nilai signifikansi Asiymp. Sig (2-tailed) sebesar 0.114 lebih besar dari 0,05. Maka sesuai dengan dasar pengambilan keputusan dalam uji normalitas Kolmogorov-Smirnov di atas, dapat disimpulkan bahwa data berdistribusi normal. Dengan demikian, asumsi atau persyaratan normalitas dalam model regresi sudah terpenuhi.

Tabel 1 Uji Normalitas Data Efikasi Diri terhadap Hasil Belajar

\begin{tabular}{|c|c|c|}
\hline & & $\begin{array}{l}\text { Unstandardiz } \\
\text { ed Residual }\end{array}$ \\
\hline $\mathrm{N}$ & & 40 \\
\hline \multirow[t]{2}{*}{ Normal Parameters ${ }^{a \cdot b}$} & Mean & .0000000 \\
\hline & Std. Deviation & 6.72419063 \\
\hline \multirow[t]{3}{*}{ Most Extreme Differences } & Absolute & .189 \\
\hline & Positive & .126 \\
\hline & Negative & -.189 \\
\hline Kolmogorov-Smirnov $Z$ & & 1.197 \\
\hline Asymp. Sig. (2-tailed) & & .114 \\
\hline
\end{tabular}

a. Test distribution is Normal.

b. Calculated from data.

Tabel 2. Uji Korelasi Data Efikasi Diri Terhadap Hasil Belajar

\begin{tabular}{|l|l|c|c|}
\hline \multicolumn{2}{|l|}{} & Efikasi Diri & Hasil Belajar \\
\hline Efikasi Diri & Pearson Correlation & $\mathbf{1}$ & $\mathbf{. 8 9 5 *}$ \\
\hline & Sig. (2-tailed) & & $\mathbf{0 0 0}$ \\
\hline & N & $\mathbf{4 0}$ & $\mathbf{4 0}$ \\
\hline Hasil Belajar & Pearson Correlation & $\mathbf{. 7 4 5}$ & $\mathbf{1}$ \\
\hline & Sig. (2-tailed) & $\mathbf{. 0 0 0}$ & $\mathbf{4 0}$ \\
\hline & N & $\mathbf{4 0}$ & \\
\hline
\end{tabular}




\section{Uji Hipotesis}

Berdasarkan output SPSS pada Tabel 2 diatas, kita akan melakukan penarikan kesimpulan dengan merujuk pada ke -3 dasar pengambilan keputusan dalam analisis korelasi bivariate person di atas.

1) Berdasarkan Nilai Signifikansi Sig. (2tailed): Dari tabel output di atas diketahui nilai Sig. (2 - tailed) antara Efikasi Diri (X1) dengan Hasil Belajar (Y) adalah sebesar $0.000<0.05$, yang berarti terdapat korelasi yang signifikan antara variabel Efikasi Diri (X1) dengan hasil belajar (Y).

2) Berdasarkan Nilai $r$ hitung (Pearson Correlations): Diketahui nilai $r$ hitung untuk hubungan Efikasi Diri (X1) dengan Hasil Belajar (Y) adalah sebesar 0.895> 0.413, maka dapat disimpulkan bahwa ada hubungan atau korelasi antara variabel Efikasi Diri (X1) dengan variabel Hasil Belajar (Y).

3) Berdasarkan tanda bintang (*) SPSS diketahui bahwa nilai Pearson Correlation antara masing - masing variabel yang dihubungkan mempunyai dua tanda bintang (**) maka berarti terdapat korelasi antara variabel yang dihubungkan dengan taraf signifikansi $1 \%$.

Karena $\mathrm{r}$ hitung atau Pearson Correlations dalam analisis ini bersifat positif maka hubungan antara kedua variabel tersebut bersifat positif atau dengan kata lain semakin meningkatnya atau semakin baiknya Efikasi Diri maka akan meningkat pula hasil belajar dari mahasiswa itu sendiri.

Berdasarkan hasil penelitian, dapat diambil kesimpulan bahwa efikasi diri memberikan pengaruh positif terhadap hasil belajar dari mahasiswa. Artinya semakin meningkatnya atau semakin baiknya efikasi diri maka akan meningkat pula hasil belajar dari mahasiswa itu sendiri. Temuan ini sejalan dengan penelitian terdahulu oleh (Sihaloho, 2018) dengan hasil peneltian bahwa efikasi diri berpangaruh positif dan signifikan terhadap hasil belajar siswa sebesar $60.5 \%$.

Hasil penelitian juga menunjukkan bahwa Motivasi Belajar memberikan pegaruh positif terhadap hasil belajar. Artinya semakin meningkatnya atau semakin baiknya kemandirian belajar maka akan meningkat pula hasil belajar dari mahasiswa itu sendiri. Temuan ini sejalan dengan Susilowati (2007) dengan hasil penelitian bahwa terdapat pengaruh yang signifikan motivasi belajar terhadap hasil belajar pada siswa kelas VII SMPN 13 Semarang. Peemuan penelitian ini juga sejalan dengan Mut'ah (2014) dengan hasil penelitian bahwa motivasi belajar mempunyai pengaruh yang signifikan terhadap hasil belajar siswa pada bidang studi sejarah kebudayaan Islam.

Berdasarkan temuan penelitian ini bahwa Efikasi Diri dan Motivasi Belajar mempunyai pengaruh yang positif terhadap Hasil Belajar berbasis e-learning. Dengan kata lain semakin meningkatnya atau semakin baiknya Efikasi Diri dan motivasi belajar maka akan meningkat pula hasil belajar dari mahasiswa itu sendiri. Temuan ini sejalan dengan Yuliana, (2019) dengan hasil penelitiannya yaitu efikasi dairi dan motivasi belajar berpengaruh positif secara langsung terhadap hasil belajar biologi.

\section{SIMPULAN DAN SARAN}

\section{Simpulan}

Berdasarkan hasil penelitian, dapat ditarik kesimpulan sebagai jawaban dari hasil penelitian yaitu berdasarkan uji hipotesis 1 dan 2, yang dilihat dari nilai $r$ hintung atau Pearson Correlations dengan melihat hubungan antara variabel efikasi diri bersifat positif maka dapat dinyatakan bahwa semakin baik efikasi diri maka akan meningkatkan hasil belajar mahasiswa menjadi lebih baik dengan hasil yang memuaskan.

\section{Saran}

Saran peneliti berkaitan dengan hasil penelitian adalah dalam proses pembelajaran baik di lingkungan sekolah maupun di lingkungan universitas, sebaiknya guru atau dosen dapat menumbuhkan sikap efikasi diri. Bagi anak didik efikasi diri dapat 
mempengaruhi hasil belajar anak didik sehingga proses pembelajaran dapat dikatakan berhasil.

\section{DAFTAR PUSTAKA}

Alwisol. (2005). Psikologi Kepribadian. UMM Press.

Christiana, R. (2018). Keefektifan Peer Modeling Untuk Meningkatkan Efikasi Diri Akademik Mahasiswa Dalam Menguasai Keterampilan Berbahasa Inggris (Vol. 3, Issue 22).

Hamalik Oemar. (2008). Proses Belajar Mengajar. Bumi Aksara.

Johnson, A. . (2017). Exploration of factors affecting the self-efficacy of Asynchronous online learners.

Nakayama M, Yamamoto H, \& S. R. (2005). The Impact of Learner Characterics on Learning Performance in Hybrid Courses among Japanese Students. . . Elektronic Journal ELearning, 5(3).

Rahmawati, Tri, N. dan S. (2016). Analisis Kemampuan Berpikir Kreatif Matematik Ditinjau Dari Kesadaran Metakognisi SIswa Pada Pembelajaran SSCS Berbantuan Schoology. Journal of Mathematics Education Research, 5 (1).

Yuliana, R. A., \& Widyan, R. (2019). Efikasi diri yang positif sangat berperan penting dalam meningkatkan motivasi belajar bahasa inggris mahasiswa. IKRA-ITH HUMANIORA: Jurnal Sosial dan Humaniora, 3(3), 102-111.

Sihaloho, L. (2018). Pengaruh Efikasi Diri (Self Efficacy) Terhadap Hasil Belajar Ekonomi Siswa Kelas Xi Ips Sma Negeri Se-Kota Bandung. JINoP (Jurnal Inovasi Pembelajaran), 4(1), 62. https://doi.org/10.22219/jinop.v4i1.5671

Suseno, N. M. (2012). Pengaruh Pelatihan Komunikasi Interpersonal Terhadap Efikasi dan Sebagai Pelatih Pada Mahasiswa. Keentrian Agama Repoblik Indonesia.

Yazdi, M. (2014). E-learning Sebagai Media
Pembelajaran Interaktif Berbasis Teknologi Informasi. Journal of Mathematics, 2 (1). 